\title{
An Analysis of Regional Economic Advantage and Specialization (Shift-Share Esteban Marquillas Model Approach) and Analysis of Its Accessibility in Banyumas Regency
}

\author{
By: \\ Rian Destiningsih"), Andhatu Achsa ${ }^{2)}$ \\ ${ }^{1,2)}$ Faculty of Economics and Business, Universitas Tidar \\ 1)Email: riandestiningsih24@gmail.com
}

\begin{abstract}
This study aimed (1) to identify the competitive advantage, specialization and effect of sectors allocation in Banyumas Regency in 2010-2015; (2) to identify region with the most advantageous position in terms of accessibility level. The result indicated that (1) competitive and specialized sectors in Banyumas Regency were mining and excavation sector, procurement of electricity and gas sector, construction sector, big scale trade and retail, car and motorcycle repair, transportation and warehousing sector, provision of accomodation and food and beverage sector, information and communication sector, financial and insurance services sector, real estate sector, corporate service sector, government administration sector, defense and compulsory social security, education service sector, health service and social activities sector, and other service sectors. (2) In terms of accessibility, Banyumas Regency had the second advantageous position after Purbalingga Regency when compared to regencies in Karesidenan Barlingmascakeb. Based on the accessibility of each sub-district in Banyumas Regency, the sub-district with the most advantageous position to interact with the sub-districts in Banyumas Regency was Tambak sub-district. This can be seen from the lowest CQ value of Tambak subdistrict.
\end{abstract}

Keywords: Shift-Share Esteban Marquillas, Accessibility, Connectivity Quotient.

\begin{abstract}
ABSTRAK
Penelitian ini bertujuan (1) untuk mengidentifikasi keunggulan kompetitif, spesialisasi dan pengaruh alokasi sektor di Kabupaten Banyumas pada tahun 2010-2015; (2) untuk mengidentifikasi wilayah dengan posisi yang paling menguntungkan dalam hal tingkat aksesibilitas. Hasilnya menunjukkan bahwa (1) sektor-sektor yang kompetitif dan terspesialisasi di Kabupaten Banyumas adalah sektor pertambangan dan penggalian, pengadaan sektor listrik dan gas, sektor konstruksi, perdagangan skala besar dan ritel, perbaikan mobil dan sepeda motor, transportasi dan pergudangan, penyediaan akomodasi dan sektor makanan dan minuman, sektor informasi dan komunikasi, sektor jasa keuangan dan asuransi, sektor real estate, sektor jasa korporasi, sektor administrasi pemerintah, pertahanan dan keamanan sosial wajib, sektor layanan pendidikan, layanan kesehatan dan sektor kegiatan sosial, dan sektor jasa lainnya. (2) Dalam hal aksesibilitas, Kabupaten Banyumas memiliki posisi menguntungkan kedua setelah Kabupaten Purbalingga bila dibandingkan dengan kabupaten di Barlingmascakeb Residency. Berdasarkan Kabupaten Banyumas, kecamatan dengan posisi yang paling menguntungkan untuk berinteraksi dengan kecamatan di Kabupaten Banyumas adalah sebuah kecamatan. Hal ini dapat dilihat dari nilai CQ terendah di Kecamatan Tambak.
\end{abstract}

Kata Kunci: Shift-Share Esteban Marquillas, Aksesibilitas, Connectivity Quotient. 


\section{INTRODUCTION}

Acceleration of effective regional economic development can be pursued by empowering the actors and local potentials, as well as observing the spatial arrangement, both physical and social so that there is equality of economic growth in line with the implementation of regional autonomy (Suparno, 2008: 5). Regional potentials in the form of natural resources or superior commodities owned by the region become an important supporting factor as capital for regional economic development. Sjafrizal (1997) in Taruna (2008:3) emphasizes that to achieve the development goals of a region, the main policy that needs to be conducted is to maximize the development priorities in accordance with the regional potentials. Thus, all the existing regional potentials can be maximally utilized in order to support regional economic development and spur regional economic growth. However, development disparities between regions in Indonesia are likely to occur. This is because every region in Indonesia has different regional characteristics, whether by population, geography, social, culture, or regional political situation. This condition also causes the different resources and potentials of each region.

Differences in regional capacity (natural resources, human resources, financial resources, institutions and local assets) are one of the obstacles in regional economic development. This inequality also has implications for different regional needs. Therefore, well-constructed development plan is required to ensure that regional economic development can be successfully implemented. Development priorities should be determined in accordance with the needs of every region with reference to economic resources and regional potentials.

\section{LITERATURE REVIEW}

Bayu Wijaya and Hastarini Dwi Atmanti in Dinamika Pembangunan, No. 2 of 2006 conducted a research on regional development and potential sectors to encourage development in Salatiga city using location quotient and shift share analysis tools and calculating interregional interactions with gravity analysis. The result indicated that potential sectors to be developed in Salatiga city were building, transportation and communication, finance, leasing, corporate service, and service sectors. While from gravity analysis, it can be determined that Salatiga city had a strong interaction with Semarang Regency due to the distance of the two adjacent regions.

In 2007, Choliq Sabana conducted a similar research on the analysis of development of Pekalongan city as one of the mainstay regions in Central Java. The research was conducted by using Klassen typology analysis, overlay, shift share, and gravity analysis. The result of overall analysis found that Pekalongan city was considered not ready to become a mainstay region because it was not included in the category of developed and fast growing region. Nevertheless, Pekalongan city had several economic sectors as its advantages, namely financial sector and trade services with competitive advantage and specialized. The result of gravity analysis showed the gravity index during observation period from 2003 to 2005, the value of gravity index of Pekalongan City with Batang and Kajen indicated the highest gravity index value and had an increasing tendency. Thus, the development of Pekalongan city should be conducted by considering the relationship between Batang Regency and Kajen Regency as buffer zones.

Siti Fatimah Nurhayati and Haris in Jurnal Ekonomi Pembangunan volume 3 number 1 of 2002 conducted a research on determination of sector specialization in Boyolali Regency in facing the implementation of regional autonomy during the financial crisis of 1997-1998 by using location quotient and shift share analysis tools. The result indicated that (1) superior sectors in Boyolali Regency were agriculture and trade sectors; (2) based on the average classical shift-share, the agriculture sector was the only sector with positive value. Meanwhile, the result of Shift-share Esteban-Marquilas indicated that two sectors that were specialized were agriculture and trade sectors, so that the sectors deserved the priority of economic development.

\section{RESEARCH METHOD}

\section{Research Object}

The research object is Banyumas Regency. 


\section{Type and Data Source}

The data needed in this research are GRDP data based on 2010 constant price according to business field in 2010-2015 in Banyumas Regency and Central Java Province, and distance between Banyumas Regency and Regencies in Karesidenan Barlingmascakeb.

\section{Shiftshare Esteban Marquilas (SS-EM)}

It is a modified classic shiftshare analysis. The modifications include defining the position or competitive advantage as the third component and creation of the fourth component, namely location effect.

\begin{tabular}{|c|c|c|}
\hline & rij-rin $>0$ & rij-rin $<0$ \\
\hline$E_{i j}-E^{\prime} i j>0$ & $\begin{array}{l}\text { Competitive } \\
\text { Specialized }\end{array}$ & $\begin{array}{l}\text { Uncompetitive } \\
\text { Specialized }\end{array}$ \\
\hline$E i j-E^{\prime} i j<0$ & $\begin{array}{c}\text { Competitive } \\
\text { Unspecialized }\end{array}$ & $\begin{array}{l}\text { Uncompetitive } \\
\text { Unspecialized }\end{array}$ \\
\hline
\end{tabular}

\section{Connectivity Quotient (CQ)}

$\mathrm{CQ}$ analysis is used to describe intercity access within a region. The calculation of $\mathrm{CQ}$ is performed in the following procedures (Bendavid-Val, 1991: 160).

(1) Calculate distance from a regency to another within a region.

(2) Calculate total distance of all regencies, then divide it by the number of regencies to obtain regional average.

(3) Divide the total distance of each regency by regional average to obtain the value of connectivity quotient.

The criteria for measuring connectivity quotient is that if $C Q<1$, it means that the accessibility level of a city is higher. Conversely, if $C Q>1$, it means that the accessibility level of a city is lower.

\section{RESULT AND DISCUSSION}

\section{Shiftshare Esteban Marquilas (SS-EM) Analysis}

The classic shift share includes three components, namely national growth, proportional growth and regional share growth components. While Shiftshare Esteban Marquilas has four components, the three components are the same as classic shift share and the additional linkage is regional share growth broken down into specialized component and competitive component, these two components are called allocation effect component.

Based on the calculation result of shiftshare esteban marquillas of Banyumas Regency in 20102015, the competitive and specialized sectors are mining and excavation sector, procurement of electricity and gas sector, construction sector, big scale trade and retail, car and motorcycle repair, transportation and warehousing sector, provision of accomodation and food and beverage sector, information and communication sector, financial and insurance service sector, real estate sector, corporate service sector, government administration sector, defense and compulsory social security, education service sector, health service and social activities sector, and other service sectors. In summary, the economic sector advantages of Cirebon City are presented in the following table. 
Table 2. Calculation Result of Shiftshare Esteban Marquilas of Banyumas Regency in 2010-2015

\begin{tabular}{lcc}
\hline \multicolumn{1}{c}{ Sector } & Specialized & Competitive \\
\hline Agriculture, forestry and fisheries & No & Yes \\
Mining and excavation & Yes & Yes \\
Processing industry & No & Yes \\
Procurement of electricity and gas & Yes & Yes \\
Water supply, waste management, waste and recycling & Yes & No \\
Construction & Yes & Yes \\
Big scale trade and retail, car and motorcycle repair & Yes & Yes \\
Transportation and warehousing & Yes & Yes \\
Provision of accomodation and food and beverage & Yes & Yes \\
Information and communication & Yes & Yes \\
Financial service and insurance & Yes & Yes \\
Real estate & Yes & Yes \\
Corporate service & No & Yes \\
Government administration, defense and compulsory social security & Yes & Yes \\
Education service & Yes & Yes \\
Health service and social activities & Yes & Yes \\
Other services & Yes & Yes \\
\hline
\end{tabular}

Table 3. Identification of competitiveness of Banyumas Regency in Central Java Province in 2010-2015

\begin{tabular}{lc}
\hline Description & Value \\
\hline Regional Economic Growth (Dj) & $8,147,933$ \\
Central Java Share (Nj) & $2,537,824$ \\
Differential Shift (Cj) & $5,610,109$ \\
\hline
\end{tabular}

Based on the calculation result of shiftshare esteban marquilas, it can be concluded that Banyumas Regency has high competitiveness because the value of Differential Shift (Cj) is higher than Central Java Share $(\mathrm{Nj})$. A region is considered to have high competitiveness if the change of GRDP of the region (regional economic growth/Dj) is affected by competitive advantage. This can be seen from the value of regional competitive advantage effect (differential shift/Cj) which is higher than the economic growth of reference area (national economic growth/Nj)

\section{Connectivity Quotient (CQ)}

Connectivity quotient analysis is used to describe intercity access within a region. The criteria for measuring connectivity quotient is that if $\mathrm{CQ}<1$, it means that the accessibility level of a city is higher. Conversely, if $C Q>1$, it means that the accessibility level of a city is lower.

Based on the calculation result of connectivity quotient, it can be concluded that (1) Purbalingga Regency has an advantageous position in interacting with other regencies of institution members of Barlingmascakeb areas. This can be seen from the lowest CQ value of Purbalingga Regency. (2) Kebumen Regency has a disadvantageous position in interacting with other regencies of institution members of Barlingmascakeb areas. This can be seen from the highest CQ value of Kebumen Regency.

Based on the calculation result of connectivity quotient per sub-district in Banyumas Regency, it can be concluded that (1) Tambak Sub-District has an advantageous position in interacting with sub-districts in Banyumas Regency. This can be seen from the lowest CQ value of Tambak sub-district. (2) West Purwokerto sub-district has a disadvantageous position in interacting with sub-districts in Banyumas Regency. This can be seen from the CQ value of sub-districts in Banyumas Regency. 
Table 4. Calculation of CQ of BARLINGMASCAKEB

\begin{tabular}{lcc}
\hline \multicolumn{1}{c}{ Sub-district } & CQ & Rank \\
\hline Banjarnegara & 1.19 & 3 \\
Purbalingga & 0.69 & 9 \\
Banyumas & 0.75 & 11 \\
Cilacap & 1.03 & 19 \\
Kebumen & 1.34 & 15 \\
\hline
\end{tabular}

Table 5. Calculation of CQ of Sub-districts in Banyumas Regency

\begin{tabular}{lcc}
\hline \multicolumn{1}{c}{ Sub-district } & CQ & Rank \\
\hline Lumbir & 1.3361 & 3 \\
Wangon & 1.0322 & 9 \\
Jatilawang & 1.0093 & 11 \\
Rawalo & 0.7996 & 19 \\
Kebasen & 0.9394 & 15 \\
Kemranjen & 1.0127 & 10 \\
Sumpiuh & 1.2797 & 4 \\
Tambak & 1.4146 & 1 \\
Somagede & 0.9929 & 13 \\
Kalibagor & 0.7885 & 20 \\
Banyumas & 0.8344 & 18 \\
Patikraja & 0.7154 & 24 \\
Purwojati & 1.1148 & 7 \\
Ajibarang & 0.9566 & 14 \\
Gumelar & 1.3556 & 2 \\
Pekuncen & 1.1307 & 6 \\
Cilongok & 1.1665 & 5 \\
Karanglewas & 0.7388 & 23 \\
Kedungbanteng & 1.0017 & 12 \\
Baturraden & 1.0610 & 8 \\
Sumbang & 0.8927 & 16 \\
Kembaran & 0.8558 & 17 \\
Sokaraja & 0.7787 & 21 \\
Purwokerto Selatan & 0.6896 & 25 \\
Purwokerto Barat & 0.6729 & 27 \\
Purwokerto Timur & 0.6843 & 26 \\
Purwokerto Utara & 0.7456 & 22 \\
\hline
\end{tabular}

\section{CONCLUSION}

Shiftshare Esteban Marquillas (SS-EM) is a tool used to identify competitive sectors or business fields in Banyumas Regency in 2010-2015. Competitive and specialized sectors in Banyumas Regency were mining and excavation sector, procurement of electricity and gas sector, construction sector, big scale trade and retail, car and motorcycle repair, transportation and warehousing, provision of accomodation and food and beverage, information and communication sector, financial and insurance service sector, real estate sector, corporate service sector, education service sector, health service and social activities sector, and other service sectors. Banyumas Regency had high competitiveness because the value of Differential Shift $(\mathrm{Cj})$ was greater than Central Java Share $(\mathrm{Nj})$.

Connectivity quotient (CQ) is a tool to identify the area which has the most advantageous position in terms of accessibility level. In this research, $C Q$ is calculated from two points of view, namely the comparison between Banyumas Regency and Karesidenan Barlingmascakeb, and between $C Q$ of each sub-district and the capital of Banyumas Regency. 
The calculation of $\mathrm{CQ}$ of Banyumas Regency compared to Karesidenan Barlingmascakeb stated that Purbalingga Regency had an advantageous position in interacting with other regencies of institution members of Barlingmascakeb areas.

Based on the calculation result of CQ of sub-districts in Banyumas Regency, it was stated that (1) Tambak sub-district had an advantageous position in interacting with sub-districts in Banyumas Regency. This can be seen from the lowest value of CQ of Tambak sub-district. (2) West Purwokerto sub-district had a disadvantageous position in interacting with the sub-districts in Banyumas Regency. This can be seen from the value of CQ of sub-districts in Banyumas Regency.

Development of Banyumas Regency should be conducted by spurring the performance of economic sector in order to grow fast and make a big contribution in generating GRDP. Investment, incentive, and other economic policies primarily need to be directed to economic activities of sectors that have both competitive and specialization. One strategy is to seek the economic sector in accordance with the contribution in generating GRDP. Seventeen economic sectors are developed according to the time period, this can be conducted in three stages, namely economic development priorities for short, medium and long term. For the short term, the Government of Banyumas Regency should focus on developing sectors or economic activities that fall into the category of competitive and specialized sectors in order to encourage faster growth. In the medium term, the Government of Banyumas Regency should seek a sector that is competitive but unspecialized sector by increasing the share of outputs in the regional economy, and uncompetitive but specialized sector is sought to be a prime sector in the long term.

In addition, supports in terms of infrastructure quality, such as the quality of road, road width, street light, and supporting policies such as location point to invest and adequate spatial planning are required. Thus, it is expected that the mobility of economic resources between sub-districts in Banyumas will run more smoothly, so that the inter-regional interaction is expected to encourage regional economic performance and ultimately provides spread effect to the surrounding areas.

\section{REFERENCES}

Andi Posman Simamora, Sirojuzilam dan Supriadi. 2013. Analisis potensi sektor pertanian terhadap pengembangan wilayah di Kabupaten Humbang Hasundutan. Jurnal Ekonomi, Vol 16, No 2, April, 2013 (pages 54-66)

Bayu Wijaya and Hastarini Dwi Atmanti. 2006. Analisis Pengembangan Wilayah dan Sektor Potensial Guna Mendorong Pembangunan di Kota Salatiga. Dinamika Pembangunan, No. 2 December, 2006 (pages $101-118$ )

Ni Luh Aprilia Kesuma and I Made Suyana Utama. 2015. Analisis sektor unggulan dan pergeseran pangsa sektor-sektor ekonomi Kabupaten Klungkung. E-Jurnal Ekonomi Pembangunan Udayana University March, 2015 Vol. 4, No. 3 (pages: 169 - 179)

Nurhayati, Siti Fatimah and Haris. 2002. Analisis Penentuan Spesialisasi Sektor di Kabupaten Boyolali dalam Menghadapi Implementasi Otonomi Daerah Masa Krisis Ekonomi 1097-1999. Jurnal Ekonomi Pembangunan Volume 3 Nomor 1.

Sabana, Choliq. 2007. Analisis Pengembangan Kota Pekalongan Sebagai Salah Satu Kawasan Andalan di Jawa Tengah. Thesis. Master of Economics and Development Studies, Diponegoro University. Semarang. (Not Published). 